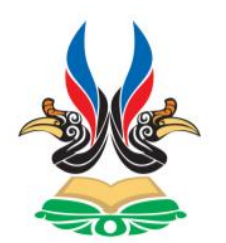

SPECTA Journal of Technology

E-ISSN : 2622-9099

P-ISSN : 2549-2713

Homepage jurnal: https://journal.itk.ac.id/index.php/sjt

\title{
Identifikasi Tingkat Inflasi Nasional Berdasarkan Cost Push Inflation Menggunakan Metode Pemrograman Dinamis
}

\author{
Kirana Damayanti Putri Hapsari ${ }^{1}$, Suhud Wahyudi ${ }^{2}$, Sentot Didik Surjanto ${ }^{3}$ \\ ${ }^{1,2,3}$ Departemen Matematika, Fakultas Sains dan Analitika Data, Institut Teknologi Sepuluh Nopember, \\ Surabaya. Email: kirana16@mhs.matematika.its.ac.id
}

\begin{abstract}
Inflation is an increase in the price of goods and services continuously and at a certain time. Inflation control must be carried out in accordance with the considerations of the government's efforts in determining monetary policy in economic strategy. Dynamic Programming is used to make interrelated decision by considering a general approach and independent variables. The independent variables used are the output gap, the discount factor, and the period value in the loss function considering the exchange rate and the average national price of food commodities (rice, chilies, and shallots) in 2019. The implementation of the Dynamic Programming method shows that more optimal values are obtained where some optimal values are marginally lower than the actual values, except in March and December 2019. In March 2019, the actual inflation rate was $2.48 \%$ and the identified inflation rate was $2.52 \%$. Meanwhile, in December 2019, the actual inflation rate was $2.72 \%$ and the identified inflation rate was $2.74 \%$.
\end{abstract}

Keywords: Dynamic Programming, Identification, Inflation.

\begin{abstract}
Abstrak
Inflasi adalah kenaikan harga barang dan jasa secara terus menerus dan dalam waktu tertentu. Pengendalian inflasi harus dilakukan sesuai dengan pertimbangan sebagai upaya pemerintah dalam menentukan kebijakan moneter pada strategi ekonomi. Pemrograman dinamis digunakan untuk membuat suatu keputusan yang saling berkaitan dengan mempertimbangkan pendekatan umum dan memperhatikan variabel independen. Variabel independen yang digunakan, yaitu output gap, diskon faktor, dan nilai periode dalam loss function dengan mempertimbangkan nilai tukar uang dan rata-rata harga komoditas pangan nasional (beras, cabai merah, dan bawang merah) pada tahun 2019. Penerapan metode Pemrograman Dinamis menunjukkan bahwa secara keseluruhan diperoleh identifikasi nilai yang lebih optimal (nilai inflasi hasil identifikasi lebih rendah dari pada nilai inflasi aktualnya), kecuali bulan Maret dan Desember 2019. Pada bulan Maret 2019, nilai inflasi aktual 2,48\% dan nilai inflasi hasil identifikasi 2,52\%. Sedangkan bulan Desember 2019, nilai inflasi aktual 2,72\% dan nilai inflasi hasil identifikasi 2,74\%.
\end{abstract}

Kata Kunci: Identifikasi, Inflasi, Pemrograman Dinamis.

\section{Pendahuluan}

Salah satu parameter penting bagi sebuah negara dalam memperbaiki sistem perekonomian adalah stabilitas ekonomi. Perkembangan ekonomi dan keuangan dunia dapat terjadi dengan sangat tidak me- 
nentu dan menimbulkan ancaman terhadap perekonomian di berbagai negara. Keadaan tidak pasti dalam perekonomian menimbulkan tantangan bagi pengelola ekonomi yang dapat ditunjukkan dari aspek perdagangan maupun aspek finansial (Bank Indonesia, 2020). Pembangunan ekonomi harus memberikan manfaat bagi seluruh lapisan masyarakat agar dapat mewujudkan stabilitas perekonomian dengan mendorong lebih banyak kegiatan ekonomi menjadi lebih aktif dan produktif.

Di Negara Republik Indonesia Bank Indonesia sebagai bank sentral, memiliki tujuan untuk mencapai dan memelihara kestabilan nilai rupiah. Tujuan tersebut tercantum dalam UU No. 23 Tahun 1999 tentang Bank Indonesia, yang sebagaimana diubah melalui UU No. 3 Tahun 2004 dan UU No. 6 Tahun 2009 pada pasal 7 (Bank Indonesia, 2018). Menurut undang-undang tersebut disebutkan bahwa kestabilan nilai rupiah dibagi menjadi dua perspektif, yaitu kestabilan terhadap harga-harga barang dan jasa berdasarkan perkembangan laju inflasi, dan perkembangan nilai tukar rupiah terhadap mata uang negara lain. Bank Indonesia menjalankan tugasnya untuk melakukan kebijakan moneter dengan mengendalikan jumlah uang beredar, yang termasuk dalam besaran moneter (Utari dkk., 2015).

Salah satu upaya Bank Indonesia dalam menjaga kestabilan ekonomi adalah melakukan pengawasan dan pengendalian inflasi. Inflasi adalah peningkatan harga barang dan jasa secara umum dan terus menerus dalam jangka waktu tertentu. Kenaikan harga dari satu atau dua barang saja tidak dapat disebut inflasi kecuali bila kenaikan itu mengakibatkan kenaikan harga barang lainnya (Bank Indonesia, 2018). Kenaikan harga barang dan jasa dapat menyebabkan nilai uang menurun, sehingga inflasi adalah penurunan nilai uang terhadap nilai barang dan jasa secara umum. Inflasi sebagai salah satu indikator makroekonomi yang penting karena mempengaruhi nilai uang, dampaknya akan langsung dirasakan oleh masyarakat melalui kenaikan harga barang.

Dalam beberapa kasus, bank sentral mempertimbangkan besarnya prediksi nilai inflasi dimasa akan datang sebagai salah satu penentu dalam pengambilan keputusan moneter. Pengendalian inflasi harus dilakukan sesuai dengan pertimbangan, di mana dalam keadaan inflasi tinggi dan tidak stabil akan secara negatif berdampak bagi keadaan sosial ekonomi masyarakat sehingga peningkatan kesejahteraan masyarakat dapat dicapai dengan menciptakan inflasi yang rendah dan stabil (Bank Indonesia, 2018). Setiap negara menginginkan terciptanya inflasi yang rendah dan stabil bagi negaranya. Perekonomian akan berdampak positif bagi sebuah negara jika inflasi berada di tahap yang stabil dan dibawah target inflasi. Untuk memperoleh inflasi yang sesuai bagi perekonomian, diperlukan adanya optimasi sehingga hasil perhitungan inflasi menjadi lebih akurat. Hal ini dilakukan untuk saling mengatasi kelemahan dan mendapatkan hasil pengukuran yang lebih baik.

Permasalahan dalam ilmu komputer, matematika dan ekonomi dapat diselesaikan menggunakan model identifikasi optimasi pemrograman dinamis sebagai metode dalam pemecahan masalah. Pendekatan umum akan digunakan dalam penyelesaian masalah, di mana terdapat keterkaitan antara beberapa permasalahan dan diselesaikan menggunakan prinsip optimalitas (Corneujols dan Tutungu, 2006). Penelitian ini bertujuan menganalisa penerapan metode Pemrograman Dinamis untuk permasalahan identifikasi tingkat inflasi nasional dengan memperharikan faktor nilai tukar uang dan rata-rata harga komoditi pangan nasional, yaitu beras, cabai merah, dan bawang merah. Pemrograman dinamis digunakan dalam membuat rangkaian keputusan yang saling terkait sehingga mendapatkan prosedur yang runtut dan sesuai untuk menentukan keputusan optimal. Pemrograman dinamis bertujuan untuk mempermudah penyelesaian persoalan nilai efektif yang harus dicapai dan memiliki ciri khas tertentu.

\section{Metode}

Metode Pemrograman Dinamis akan dijabarkan untuk memperjelas penyelesaian pada permasalahan tersebut.

\subsection{Sumber Data}

Penelitian ini menggunakan data sekunder tahun 2019 yang diuraikan sebagai berikut:

1. Data bulanan tingkat inflasi nasional yang diperoleh dari website Bank Indonesia. 
2. Data nilai tukar uang rupiah terhadap dollar Amerika Serikat dalam satuan bulanan, diperoleh dari website Bank Indonesia.

3. Data rata-rata harga komoditi pangan nasional dalam satuan bulan, antara lain beras, cabai merah dan bawang merah, diperoleh website Kementrian Pertanian Indonesia. Ketiga bahan pokok tersebut merupakan bahan pokok yang harganya fluktuatif pada tahun 2019.

4. Data tingkat suku bunga periodik (BI 7-Day (Reverse) Repo Rate), diperoleh dari website Bank Indonesia.

5. Data nilai estimasi output gap menggunakan metode Hodrick-Prescott (HP) Filter sebesar 0,21\%, diperoleh dari artikel Kajian Ekonomi dan Keuangan, Pusat Kebijakan Ekonomi Makro, Badan Kebijakan Fiskal, Kementerian Keuangan Tahun 2018.

\subsection{Tahapan Penelitian}

Pada tahap ini, analisis optimasi tingkat inflasi nasional akan dilakukan dengan menggunakan model Pemrograman Dinamis. Adapun secara umum langkah-langkah dalam penyelesaian permasalahan sebagai berikut:

\subsubsection{Identifikasi permasalahan}

Permasalahan pada penelitian ini adalah mendapatkan hasil identifikasi dari optimasi tingkat inflasi nasional untuk menghasilkan nilai tingkat inflasi nasional yang lebih baik dan lebih sesuai.

\subsubsection{Studi literatur}

Akan dilakukan identifikasi permasalahan yang diangkat pada penelitian ini dengan mempelajari langkah-langkah dalam mendapatkan hasil penelitian yang lebih baik dari tingkat inflasi nasional dengan menggunakan metode Pemrograman Dinamis.

\subsubsection{Pengumpulan data}

Data merupakan data sekunder periode bulan Januari - Desember 2019 yang telah dijabarkan pada sumber data.

\subsubsection{Analisis model identifikasi optimal}

Pada penelitian ini dilakukan analisis terhadap 4 variabel cost push inflation dengan menggunakan model Pemrograman Dinamis untuk menghasilkan nilai inflasi nasional yang optimal. Langkah-langkah yang dilakukan dengan mempertimbangkan total nilai perhitungan ekspektasi dari 4 variabel cost push inflation, yaitu nilai tukar uang dan rata-rata harga komoditas pangan nasional (beras, cabai merah, dan bawang merah) adalah sebagai berikut:

1. Mengidentifikasi Variabel Independen dan Variabel Dependen

Variabel independen yang digunakan dalam penelitian ini, antara lain nilai tukar uang rupiah terhadap dollar Amerika Serikat, rata-rata harga komoditas pangan nasional (beras, cabai merah, dan bawang merah), output gap, dan diskon faktor. Sedangkan variabel dependen yang digunakan adalah tingkat inflasi nasional pada setiap keadaan.

2. Mengidentifikasi Variabel Keputusan Setiap Tahap

Variabel keputusan yang akan diambil pada setiap tahap adalah jumlah dari nilai ekspektasi faktor-faktor yang mempengaruhi inflasi ditinjau dari besarnya pengaruh suatu variabel yang berdampak pada besarnya inflasi berdasarkan data dari Bank Indonesia.

3. Merumuskan Persamaan Fungsi Objektif

Menentukan fungsi tujuan yang akan digunakan berdasarkan variabel independen, variabel dependen, variabel keputusan setiap stage pada sistem sehingga membentuk sebuah persamaan.

4. Penyelesaian Model Pemrograman Dinamis

Penyelesaian model berdasarkan keadaan dan variabel-variabel lainnya dengan menetapkan output yang dapat diperoleh dengan fungsi rekursif, yaitu meminimalkan nilai tingkat inflasi nasional Indonesia pada tahun 2019. Skema penyelesaian masalah dengan menggunakan metode pemrograman dinamis dapat dijabarkan pada Gambar 1. 


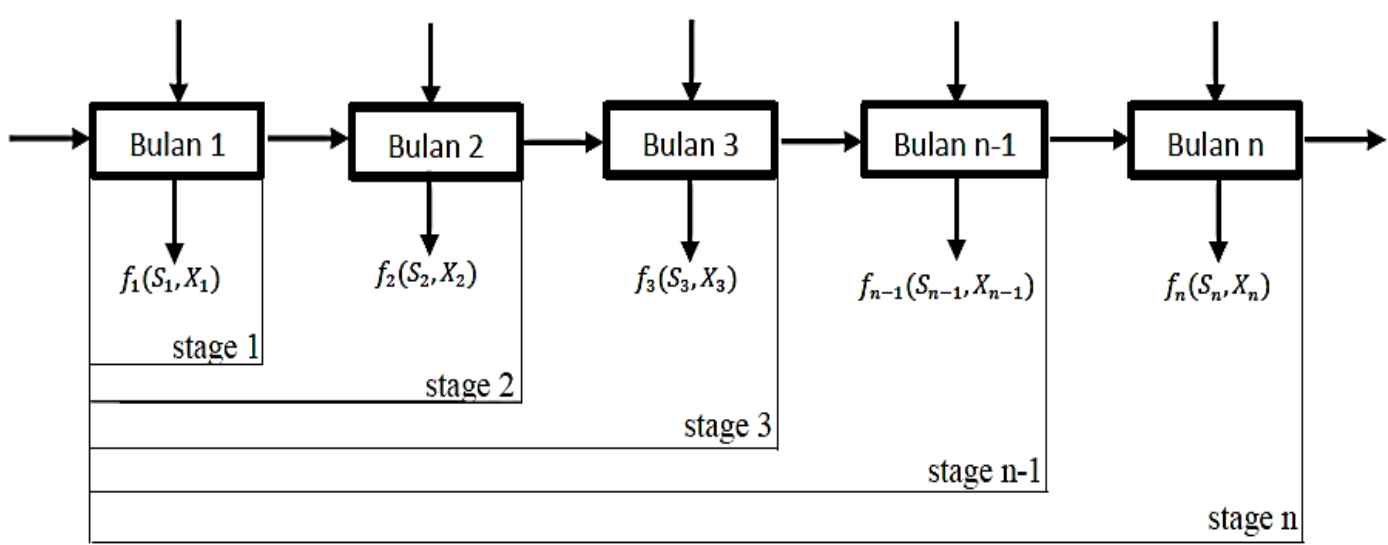

Gambar 1: Pemecahan Masalah dengan Menggunakan Metode Pemrograman Dinamis Sumber: Rencana penelitian

di mana,

$S_{n} \quad$ : keadaan yang terjadi pada tahap $n$;

$n \quad:$ tahap ke- $n$;

$X_{n} \quad$ : keputusan ke tahap selanjutnya $\left(X_{n-1}\right)$.

Pada tahap ini akan dilakukan perhitungan nilai periode dalam loss function di mana nilai loss function digunakan sebagai cara penargetan inflasi yang "fleksibel", dengan tujuan untuk menstabilkan tingkat inflasi sehingga nilainya berada di sekitar target inflasi. Diketahui bahwa $\lambda$ adalah bobot relatif pada stabilisasi output gap dengan nilai $\lambda>0$ sehingga diasumsikan bahwa $\lambda=1$, maka nilai periode dalam loss function $\left(L_{n}\right)$ adalah sebagai berikut (Svensson, 2003).

$$
L_{n}=\frac{1}{2}\left[\left(T_{n}-T^{*}\right)^{2}+\lambda \times G A P^{2}\right]
$$

di mana:

$T_{n} \quad$ : nilai aktual inflasi;

$T^{*} \quad$ : target inflasi;

$\lambda \quad$ : bobot relatif pada stabilisasi output gap $(\lambda>0)$;

GAP : nilai estimasi output gap.

Berdasarkan formula nilai ekspektasi, maka diperoleh perhitungan nilai ekspektasi pada data nilai tukar uang dan perhitungan nilai ekspektasi pada data rata-rata harga komoditas pangan nasional, yaitu beras $\left(A_{n}\right)$, cabai merah $\left(C_{n}\right)$, dan bawang merah $\left(B_{n}\right)$ adalah sebagai berikut. Diketahui bahwa $Q_{n}=A_{n}+C_{n}+B_{n}$.

$$
\begin{aligned}
& N E_{R_{n}}=\frac{1}{2} \sum_{i=0}^{k} X_{i} P\left(X_{i}\right) . \\
& N E_{Q_{n}}=\frac{1}{2} \sum_{i=0}^{k} X_{i} P\left(X_{i}\right) .
\end{aligned}
$$

Selanjutnya akan dilakukan minimasi pada tingkat inflasi nasional dengan mempertimbangkan variabel-variabel cost push inflation, yaitu nilai tukar uang dan rata-rata harga komoditas pangan 
nasional, seperti beras, cabai merah, dan bawang merah. Model formulasi perhitungan identifikasi tingkat inflasi tahun 2019 (Hillier, 2005) menggunakan metode pemrograman dinamis adalah sebagai berikut:

$$
f_{n}\left(I_{n}\right)=\sum_{n=1}^{12} I_{n}\left(R_{n}, A_{n}, C_{n}, B_{n}\right)
$$

dengan batasan:

$$
\begin{gathered}
0 \leq T_{n} \leq T^{*} ; \\
0 \leq I_{n} \leq T^{*} ; \\
0 \leq D F_{n} \leq 1 ; \\
0 \leq N E_{R_{n}} \leq 1780 ; \\
R_{n}, A_{n}, C_{n}, B_{n} \geq 0 ;
\end{gathered}
$$

di mana:

$I_{n} \quad$ : tingkat inflasi nasional pada tahap $n$;

$R_{n} \quad$ : nilai tukar rupiah terhadap dollar pada tahap $n$;

$A_{n} \quad$ : rata-rata harga eceran nasional beras pada tahap $n$;

$C_{n} \quad$ : rata-rata harga eceran nasional cabai merah pada tahap $n$;

$B_{n} \quad$ : rata-rata harga eceran nasional bawang merah pada tahap $n$;

$f_{n-1}{ }^{*} \quad$ : nilai minimum pada tahap sebelumnya $n-1$;

$f_{n}\left(I_{n}\right)$ : nilai minimum optimasi tingkat inflasi pada tahap $n$.

Secara lengkap fungsi tujuan dari identifikasi tingkat inflasi adalah sebagai berikut.

$$
f_{n}\left(I_{n}\right)=\min \left\{\left[\left(1-D F_{n}\right) \times\left(D F_{n}\right)^{2} \times L_{n} \times N E_{n}\right]+f_{n-1}^{*}\right\}
$$

sehingga,

$$
f_{n}\left(I_{n}\right)=\min \left\{\left[2,418 \times 10^{-6} \times\left(N E_{R_{n}}+N E_{Q_{n}}\right)\right]+f_{n-1}^{*}\right\}
$$

dengan batasan:

$$
\begin{gathered}
0 \leq T_{n} \leq T^{*} ; \\
0 \leq I_{n} \leq T^{*} ; \\
0 \leq D F_{n} \leq 1 ; \\
0 \leq N E_{R_{n}} \leq 1780 .
\end{gathered}
$$


5. Analisis Penyelesaian Masalah

Melakukan perhitungan hasil dari penerapan metode Pemrograman Dinamis dan dilakukan penentuan tingkat inflasi nasional melalui fungsi objektif yang dibentuk berdasarkan kendala yang ada.

\section{Hasil dan Pembahasan}

Langkah yang dilakukan setelah dilakukan pengumpulan dan pengolahan data, diperoleh data yang sesuai untuk melakukan identifikasi pada tingat inflasi nasional. Perhitungan nilai diskon faktor, nilai periode dalam loss function, nilai ekspektasi pada variabel, dan penyelesaian pemecahan masalah dengan metode pemrograman dinamis.

\subsection{Perhitungan Diskon Faktor}

Diskon faktor merupakan suatu faktor bilangan menentukan nilai yang digunakan pada hari nanti dari nilai yang sekarang, dengan mempertimbangkan tingkat bunga yang tetap pada akhir tahun. Dengan $p$ adalah tingkat suku bunga periodik (BI 7-Day Repo Rate) dan $l$ adalah jumlah pembayaran, maka diperoleh nilai diskon faktor adalah sebagai berikut.

Tabel 1: Rata-Rata Diskon Faktor (\%) setiap bulan pada tahun 2019

\begin{tabular}{|c|c|c|}
\hline Bulan & Diskon Faktor (DF) & $(\mathrm{DF})^{2}$ \\
\hline Januari & 49,70 & 24,70 \\
\hline Februari & 49,70 & 24,70 \\
\hline Maret & 49,70 & 24,70 \\
\hline April & 49,70 & 24,70 \\
\hline Mei & 49,70 & 24,70 \\
\hline Juni & 49,70 & 24,70 \\
\hline Juli & 51,13 & 26,14 \\
\hline Agustus & 52,60 & 27,67 \\
\hline September & 54,12 & 29,29 \\
\hline Oktober & 55,68 & 31,01 \\
\hline November & 55,68 & 31,01 \\
\hline Desember & 55,68 & 31,01 \\
\hline Total & 623,07 & 324,30 \\
\hline Rata-Rata & 51,92 & 27,02 \\
\hline
\end{tabular}

\subsection{Perhitungan Nilai Periode dalam Loss Function}

Nilai aktual inflasi adalah suatu nilai tingkat inflasi yang sudah ditetapkan dan diumumkan oleh pemerintah pada setiap bulannya. Target inflasi $\left(T^{*}\right)$ pada tahun 2019 ditetapkan sebesar $3,5 \pm 1 \%$ (Bank Indonesia, 2020). Diasumsikan bahwa target inflasi setiap bulan pada tahun 2019 sebesar 3,5\%. Dengan menggunkan Persamaan (1) maka diperoleh nilai periode dalam loss function yang selengkapnya ditampilkan pada Tabel 2. 
Tabel 2: Perhitungan nilai periode dalam Loss Function inflasi tahun 2019

\begin{tabular}{|c|c|c|}
\hline Bulan & Nilai Aktual Inflasi $\left(T_{n}\right)$ & Loss Function $\left(L_{n}\right)$ \\
\hline Januari & $2,82 \%$ & $2,5325 \times 10^{-5}$ \\
\hline Februari & $2,57 \%$ & $4,545 \times 10^{-5}$ \\
\hline Maret & $2,48 \%$ & $5,4225 \times 10^{-5}$ \\
\hline April & $2,83 \%$ & $2,465 \times 10^{-5}$ \\
\hline Mei & $3,32 \%$ & $3,825 \times 10^{-6}$ \\
\hline Juni & $3,28 \%$ & $4,625 \times 10^{-6}$ \\
\hline Juli & $3,32 \%$ & $3,825 \times 10^{-6}$ \\
\hline Agustus & $3,49 \%$ & $2,21 \times 10^{-6}$ \\
\hline September & $3,39 \%$ & $2,281 \times 10^{-6}$ \\
\hline Oktober & $3,13 \%$ & $9,05 \times 10^{-6}$ \\
\hline November & $3,00 \%$ & $1,1471 \times 10^{-5}$ \\
\hline Desember & $2,72 \%$ & $3,2625 \times 10^{-5}$ \\
\hline Total & - & $2,2333 \times 10^{-4}$ \\
\hline Rata-Rata & - & $1,861 \times 10^{-5}$ \\
\hline
\end{tabular}

Sumber: Data website Bank Indonesia dan hasil perhitungan.

\subsection{Perhitungan Nilai Ekspektasi Pada Variabel}

Nilai ekspektasi dari empat variabel, yaitu nilai tukar uang rupiah terhadap dollar Amerika Serikat tahun 2019 dan rata-rata harga komoditas pangan nasional, yaitu beras, cabai merah, dan bawang merah tahun 2019. Nilai ekspektasi atau nilai harapan adalah suatu konsep dalam statistik untuk membantu dalam pengambilan keputusan. $N E_{R_{n}}$ adalah nilai perhitungan ekspektasi yang bergantung dalam informasi pada nilai tukar uang (kurs) pada setiap bulannya dan $N E_{Q_{n}}$ adalah penjumlahan dari nilai perhitungan ekspektasi yang bergantung dalam informasi pada harga komoditas pangan nasional, yang terdiri dari beras, cabai merah, dan bawang merah. Tabel 3 merupakan nilai perhitungan ekspektasi pada variabelvariabel yang mempengaruhi inflasi tahun 2019 diperoleh dengan menggunakan Persamaan (2) dan Persamaan (3). 
Tabel 3: Nilai perhitungan ekspektasi pada variabel pengaruh inflasi tahun 2019

\begin{tabular}{lll}
\hline \multicolumn{1}{c}{ Bulan } & \multicolumn{1}{c}{$N E_{R_{n}}$} & $N E_{Q_{n}}$ \\
\hline Januari & 1779,239 & 8416,375 \\
Februari & 1763,171 & 7754,875 \\
Maret & 1785,263 & 8424,500 \\
April & 1776,664 & 9726,125 \\
Mei & 1808,095 & 10425,250 \\
Juni & 1787,217 & 9915,750 \\
Juli & 1764,283 & 11577,000 \\
Agustus & 1789,131 & 11114,625 \\
September & 1772,696 & 8995,125 \\
Oktober & 1773,526 & 9132,000 \\
November & 1767,383 & 9339,000 \\
Desember & 1760,942 & 9089,250 \\
\hline Total & 21327,609 & 113909,875 \\
\hline Rata-Rata & 1777,301 & 9492,490 \\
\hline Sumber: Hasil perhitungan. & &
\end{tabular}

\subsection{Pemecahan Masalah dengan Metode Pemrograman Dinamis}

Sebuah teknik matematika, yaitu metode pemrograman dinamis untuk membuat urutan kesimpulan yang saling terkait sehingga memberikan langkah runtut dan teratur untuk menentukan keputusan kombinasi yang optimal.

Dari perhitungan data-data pada Tabel 2 dan Tabel 3, diperoleh rata-rata faktor diskon yang dihitung setiap bulan pada tahun 2019, yaitu sebesar $27,02 \%$ dan perhitungan nilai periode dalam inflation loss function tahun 2019 , yaitu sebesar $1,861 \times 10^{-5} . N E_{n}$ adalah total dari nilai perhitungan ekspektasi variabel cost push inflation, yaitu nilai tukar uang dan rata-rata harga komoditas pangan nasional (beras, cabai merah, dan bawang merah). Dapat dituliskan menjadi formula yang lebih lengkap mengacu pada formula Inflation Loss Function.

Dengan menggunakan data nilai perhitungan ekspektasi variabel pengaruh inflasi tahun 2019 pada Tabel 3, hasil penyelesaian identifikasi tingkat inflasi nasional menggunakan metode pemrograman dinamis deterministik dengan rekursif maju (forward recursive) diterapkan pada Persamaan (4) adalah sebagai berikut. 
Tabel 4: Rekapitulasi identifikasi tingkat inflasi nasional tahun 2019 menggunakan metode Pemrograman Dinamis

\begin{tabular}{llll}
\hline \multicolumn{1}{c}{ Bulan } & \multicolumn{1}{c}{$\begin{array}{c}\text { Akumulasi Tingkat } \\
\text { Inflasi }\end{array}$} & \multicolumn{1}{c}{$\begin{array}{c}\text { Tingkat Inflasi } \\
\text { Optimal }\end{array}$} & $\begin{array}{c}\text { Tingkat Inflasi } \\
\text { Optimal (\%) }\end{array}$ \\
\hline Januari & 0,0264409 & 0,0264409 & 2,64 \\
Februari & 0,0518736 & 0,0254326 & 2,54 \\
Maret & 0,0770934 & 0,0252198 & 2,52 \\
April & 0,1048111 & 0,0277176 & 2,77 \\
Mei & 0,1349225 & 0,0301115 & 3,01 \\
Juni & 0,1627525 & 0,2882990 & 2,88 \\
Juli & 0,1959144 & 0,0321619 & 3,22 \\
Agustus & 0,2276484 & 0,0317340 & 3,17 \\
September & 0,2554748 & 0,0278265 & 2,78 \\
Oktober & 0,2830063 & 0,0275315 & 2,75 \\
November & 0,3103927 & 0,0273864 & 2,74 \\
Desember & 0,3377887 & 0,0273961 & 2,74 \\
\hline Source: Hasil Perhitungan & & &
\end{tabular}

Source: Hasil Perhitungan.

Menurut Bank Indonesia yang dicantumkan melalui website resminya, inflasi di Indonesia dihitung dengan Indeks Harga Konsumen (IHK) yang dikelompokkan menjadi 7 kelompok pengeluaran. Dalam penelitian ini dapat diperoleh jumlah nilai ekspektasi dari faktor-faktor yang menyebabkan inflasi dan nilai tingkat inflasi yang lebih rendah dari nilai aktualnya. Sedangkan, belum semua diketahui secara detail faktor-faktor yang menyebabkan perubahan nilai tingkat inflasi yang dapat dimasukkan ke pengolahan data, sehingga beberapa nilai perhitungan identifikasi nilainya jauh dari nilai aktual.

Berdasarkan hasil identifikasi yang telah dilakukan, diperoleh jumlah nilai ekspektasi dari 4 faktor penyebab inflasi dan nilai inflasi. Dari hasil pengolahan, dapat dilihat bahwa secara keseluruhan perhitungan hasil penelitian mendapatkan nilai yang lebih optimal, di mana nilai inflasi hasil identifikasi lebih rendah daripada nilai inflasi aktualnya, akan tetapi terdapat beberapa nilai inflasi hasil identifikasi yang melebihi nilai aktualnya, yaitu pada bulan Maret dan Desember.

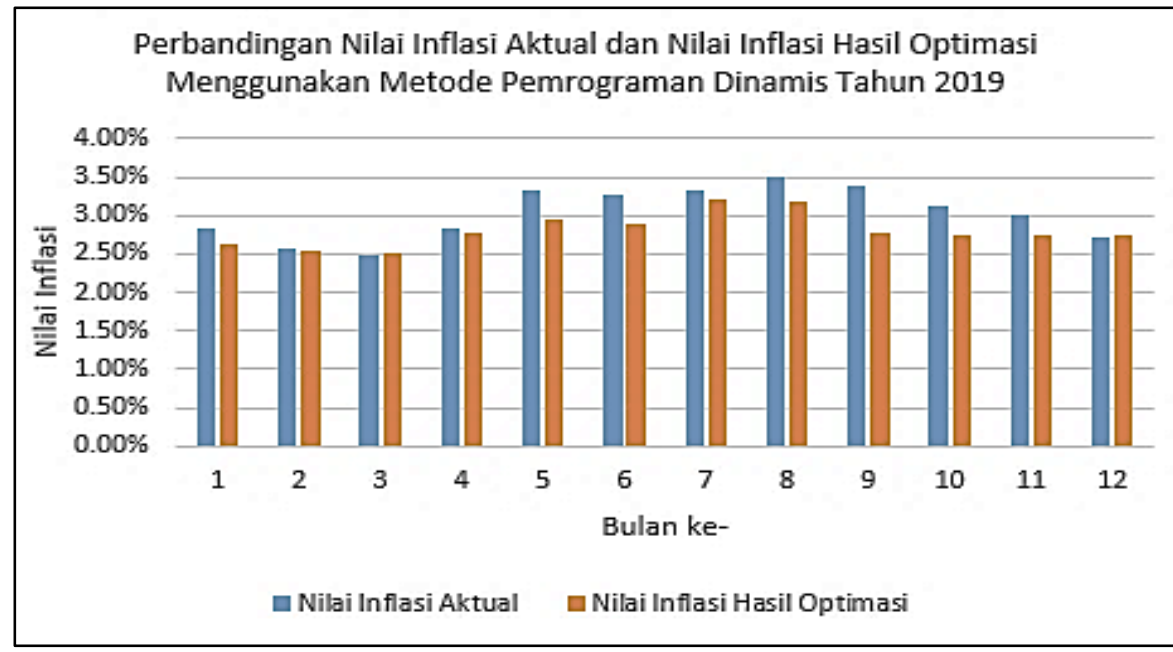

Gambar 2: Grafik Perhitungan Nilai Inflasi Aktual dan Nilai Inflasi Hasil Optimasi Tahun 2019

Sumber: Hasil perhitungan 
Tabel 5: Perbandingan perhitungan nilai inflasi aktual dan nilai inflasi hasil identifikasi tahun 2019

\begin{tabular}{llll}
\hline \multicolumn{3}{c}{ Bulan } & \multicolumn{3}{c}{$N E_{R_{n}}$} & $N E_{Q_{n}}$ \\
\hline Januari & $2,82 \%$ & $2,64 \%$ \\
Februari & $2,57 \%$ & $2,54 \%$ \\
Maret & $2,48 \%$ & $2,52 \%$ \\
April & $2,83 \%$ & $2,77 \%$ \\
Mei & $3,32 \%$ & $3,01 \%$ \\
Juni & $3,28 \%$ & $2,88 \%$ \\
Juli & $3,32 \%$ & $3.22 \%$ \\
Agustus & $3,49 \%$ & $3,17 \%$ \\
September & $3,39 \%$ & $2,78 \%$ \\
Oktober & $3,13 \%$ & $2,75 \%$ \\
November & $3,00 \%$ & $2,74 \%$ \\
Desember & $2,72 \%$ & $2,74 \%$ \\
\hline
\end{tabular}

Source: Hasil Perhitungan.

Selama periode bulan Januari - Februari 2019 dilakukan perbandingan perhitungan nilai inflasi aktual dan nilai inflasi hasil identifikasi, di mana keduanya mengalami penurunan. Nilai tukar uang, harga cabai merah, dan harga bawang merah mengalami kenaikan yang cukup besar, sedangkan harga beras cenderung turun. Pada bulan Maret - April 2019, perhitungan keduanya mengalami kenaikan. Harga cabai merah dan harga bawang merah mengalami kenaikan yang cukup besar, sedangkan nilai tukar uang dan harga beras mengalami penurunan sangat kecil.

\section{Kesimpulan}

Berdasarkan hasil penelitian dan pembahasan, terdapat beberapa kesimpulan terkait identifikasi tingkat inflasi nasional, yaitu sebagai berikut.

1. Penerapan model pemrograman dinamis pada identifikasi tingkat inflasi nasional tahun 2019 dinilai cukup baik berdasarkan perbandingan nilai inflasi aktual dan nilai inflasi hasil identifikasi, karena dapat merepresentasikan perhitungan tingkat inflasi nasional dengan mempertimbangkan nilai perhitungan ekspektasi faktor-faktor yang menyebabkan inflasi, yaitu nilai tukar uang rupiah terhadap dollar Amerika Serikat, dan rata-rata harga komoditas pangan nasional yang diatur pemerintah, diantaranya adalah beras, cabai merah dan bawang merah sehingga memperoleh hasil optimasi yang sesuai.

2. Keseluruhan perhitungan identifikasi tingkat inflasi nasional tahun 2019 diperoleh nilai yang lebih optimal dibandingkan nilai inflasi aktualnya, yaitu nilai inflasi hasil aktual lebih tinggi daripada nilai inflasi identifikasi, akan tetapi terdapat beberapa nilai inflasi hasil identifikasi yang melebihi nilai aktualnya, yaitu pada bulan Maret dan Desember 2019.

\section{Daftar Pustaka}

Bank Indonesia (2020) Laporan Perekonomian Indonesia 2019, Jakarta: Bank Indonesia.

Bank Indonesia (2018) 'Tujuan kebijakan moneter, kerangka kebijakan moneter, inflasi, dan BI 7-day (Reverse) Repo Rate', tersedia di: www.bi.go.id, diakses pada 3 Mei 2020.

Boomen, M. V. D., Berg, P. L. V. D., dan Wolfert, A. R. M. (2019) 'A dynamic programming approach for economic optimisation of lifetime-extending maintenance, renovation, and replacement of public infrastructure assets under differential inflation', Structure and Infrastructure Engineering, Vol. 15, No. 2: 193-205. 
Cornuejols, G. dan Tutungu, R. (2006) Optimization Methods in Finance, United States: Carnegie Mellon University, Pittsburgh PA 15213.

Hillier, F. S. (2005) Introduction to Operations Research Ninth Edition, New York: McGraw-Hill Companies, Inc.

Mankiw, N. G. (2016) Macroeconomics Ninth Edition, New York: Harvard University.

Nurwanda, A. dan Rifai, B. (2018) 'Diagnosis pertumbuhan ekonomi dan output potensial Indonesia', Kajian Ekonomi Keuangan, Vol. 2. No. 3: 177-194.

Ross, S. M. (2011) An Elementary Introduction to Mathematical Finance Third Edition, New York: Cambridge University Press.

Sugiharti, L., Esquivias, M. A., dan Setyorani, B. (2020) 'The impact of exchange rate volatility on Indonesia's top exports to the five main export markets', Heliyon, Vol. 6, No. 1: 1-14.

Svensson, L. E. O. (2002) 'Inflation targeting: Should it be modeled as an instrument rule or a targeting rule?', European Economic Review, Vol. 46, No. 4-5: 771-780.

Svensson, L. E.O. (2003) 'The inflation forecast and the loss function', CEPR Discussion Papers, No. 3365: 118.

Utari, G. A. D., Cristina, R., dan Pambudi, S. (2015) Inflasi di Indonesia: Karakteristik dan Pengendaliannya, Jakarta: Bank Indonesia Institute. 